\title{
KAJIAN INTERVENSI PENCEGAHAN PERILAKU SEKSUAL BERISIKO HIV DALAM PENINGKATAN SELF-EFFICACY PADA REMAJA
}

\author{
STUDY OF SEXUAL BEHAVIOR INTERVENTION PREVENTION OF HIV RISK IN \\ IMPROVED SELF-EFFICACY IN ADOLESCENT
}

\author{
Angga Wilandika \\ Program Studi Diploma III Keperawatan, STIKes 'Aisyiyah Bandung \\ Email: wiland.angga@gmail.com
}

\begin{abstract}
ABSTRAK
Pendahuluan: Perkembangan aktivitas seksual pada masa remaja menjadikan paparan terhadap infeksi HIV semakin tinggi dan apabila tidak memiliki kemampuan diri untuk mencegahnya maka akan menyebabkan resiko terjangkitnya infeksi HIV. Tujuan: penelitian ini bertujuan untuk mengidentifikasi intervensi efikasi diri dalam pencegahan perilaku seksual berisiko HIV pada remaja. Metode yang digunakan adalah kajian literatur. Penelusuran database dilakukan melalui ProQuest Nusing and Allied Health Source (Januari 2007 sampai Februari 2017), menggunakan kata kunci pencarian "self-efficacy", "HIVIAIDS", "intervention", "program" dan "adolescents". Selain itu, artikel yang dipilih dibatasi hanya pada penelitian yang menggunakan metode randomized-controlled trial (RCT). Hasil: Kajian menemukan tiga penelitian yang menggambarkan intervensi atau program yang meningkatkan efikasi diri dalam pencegahan perilaku seksual berisiko HIV. Intervensi ditemukan menggunakan teknik edukasi kesehatan atau promosi kesehatan dalam mencegah perilaku seksual berisiko HIV pada remaja. Intervensi yang ditujukan pada remaja ini berdampak terhadap keyakinan efikasi diri remaja. Pendidikan kesehatan yang dilakukan berfokus pada tingkatan individu, keluarga, komunitas, dan masyarakat serta penggunaan teknologi sebagai media pemberian edukasi kesehatan tersebut. Penulis menyimpulkan bahwa intervensi untuk meningkatkan efikasi diri pencegahan harus dilakukan secara proaktif dan berkelanjutan baik menggunakan pendekatan yang berfokus kepada individu remaja sendiri ataupun melibatkan peran serta keluarga dan masyarakat dan menggunakan teknologi komputer. Diskusi: Disarankan untuk penelitian selanjutnya mengenai intervensi berbasis teknologi yang lebih luas dan lebih dikenal oleh kalangan remaja untuk mengembangkan efikasi diri dalam pencegahan perilaku berisiko HIV.
\end{abstract}

Kata kunci: pencegahan, perilaku seksual berisiko HIV, remaja dan self-efficacy

\section{ABSTRACT}

Introduction: The sexual activity development in an early adolescence makes this age group to have higher exposure to the HIV infection. If this population has no ability to resist then it will lead to the the risk of HIV cases. Methods: This study is a literature review. ProQuest Nusing and Allied Health Source (January 2007February 2017) were searched using keyword term "self-efficacy", "HIV/AIDS", "intervention", "program" and "adolescents" In addition, the chosen article was restricted to studies using randomized-controlled trial (RCT). Paper that described an intervenstions that promote a self-efficacy in the HIV sexual risk behavior in adolescent were selected for review. Results: Three papers met the selection criteria. The interventions were found using health education or health promotion approach in preventing HIV sexual risk behavior in adolescents. Interventions have an impact to increase self-efficacy beliefs in adolescent. Health education was focused on the individual, family, and community level, as well as the technology also used for the provision of health education. nlnvestigator conclude that nurses should carried out the holistic nature of the dying experience and interventions needed to promote a peaceful death and dignity dying for patients and their family. Furthermore, interventions to improve self-efficacy of prevention should carried out proactively and sustainably. Interventions can focus on individual adolescents themselves or involve the participation of families and communities and use computer technology. Discussion: Further research is to generate a technology- 
based interventions that is broader and more known by the youth to develop self-efficacy in the prevention of HIV risk behavior.

Keywords: adolescents, HIV sexual risk behavior, prevention, and self-efficacy

\section{PENDAHULUAN}

HIV/AIDS tidak mengenal batasan usia. Semakin merebaknya infeksi HIV/AIDS tidak saja menyerang mereka yang dikatakan sebagai orang dewasa, bahkan pula menjangkit anak-anak dibawah umur dan remaja. Laporan UNAIDS (2014) menyebutkan bahwa hampir setengah dari seluruh penderita HIV baru di dunia adalah orang muda dengan usia $19-24$ tahun. Sementara itu, UNAIDS (2016) mencatat bahwa remaja usia 15-24 tahun berisiko tinggi untuk terinfeksi HIV. Pada tahun 2015, secara global terhitung sebesar $20 \%$ terjadi infeksi baru pada remaja perempuan dan $14 \%$ terjadi pada remaja laki-laki.

Masa remaja umumnya dianggap sebagai masa mencoba sesuatu hal baru dan masa dimana meningkatnya keterlibatan dalam perilaku berisiko atau masalah perilaku, termasuk kegagalan sekolah dan kabur dari sekolah, kekerasan remaja, penggunaan narkoba, dan perilaku seksual berisiko tinggi (Biglan, Brennan, Foster, \& Holder, 2004). Meskipun sebagian besar remaja menjalani tahap perkembangan ini relatif tanpa cedera, perilaku berisiko untuk beberapa remaja menjadi kronis, meningkatkan kemungkinan masalah pada beberapa hal seperti kesehatan fisik, harapan hidup, penyesuaian psikososial, dan keberhasilan transisi menuju kedewasaan (Lindberg, Boggess, \& Williams, 2000).

Banyaknya risiko yang dihadapi pada masa remaja dapat menjadi masalah bagi mereka yang tidak dapat mengatasinya dengan baik. Kegagalan sekolah dapat menyebabkan pengangguran, kekerasan dapat menyebabkan perilaku kriminal, konsumsi narkoba dapat menyebabkan kecanduan dan masalah kesehatan, dan aktivitas seksual dapat menyebabkan penyakit menular seksual seperti HIV.
Aktivitas seksual dimulai pada masa remaja untuk sebagian besar orang. Pada banyak negara, perempuan dan laki-laki yang belum menikah melakukan hubungan seksual sebelum usia mencapai 15 tahun. Remaja yang mulai berhubungan seksual dini lebih rentan terhadap HIV. Remaja mengalami perubahan baik fisik maupun emosional yang kemudian tercermin dalam perilaku. Remaja mudah terpengaruh oleh informasi baik informasi yang positif atau negatif, termasuk kegiatan yang mengarah kepada risiko untuk terkena infeksi HIV seperti pergaulan bebas dan hubungan seksual dibawah umur (UNICEF, 2002).

Bankole, Singh, Woog, and Wulf (2004), mengatakan remaja yang melakukan hubungan seksual berulang kali, dengan satu atau lebih pasangan atau berhubungan seksual yang tidak aman tanpa menggunakan pelindung akan meningkatkan risiko munculnya penyakit menular seksual dan berisiko tinggi untuk terinfeksi HIV. Lebih lanjut Blum and NelsonMmari (2004); Gregson et al. (2002) mengungkapkan bahwa remaja yang telah terinfeksi HIV memiliki kemungkinan sangat tinggi untuk menularkan pada pasangannya yang belum terinfeksi saat berhubungan seksual. Hal ini menambah risiko yang sangat tinggi pada kelompok remaja untuk tertular HIV.

Walaupun kelompok remaja ini sangat berisiko untuk tertular HIV, akan tetapi remaja sendiri merupakan "sebuah jendela kesempatan" untuk mewujudkan generasi terbebas HIV/AIDS. Dengan demikian, diperlukan langkah-langkah atau strategi termasuk penguatan terhadap aspek-aspek yang akan melindungi remaja dari berbagai kerentanan infeksi HIV sejak dini sebagai upaya pencegahan (Komisi Penanggulangan AIDS Nasional, 2015). 
Upaya yang dapat dilakukan salah satunya melalui penguatan self-efficacy dalam pencegahan infeksi HIV/AIDS pada kelompok remaja. Lee, Salman, and Fitzpatrick (2009) yang meneliti mengenai hubungan self-efficacy, gejala depresi dan perilaku seksual berisiko pada remaja menemukan bahwa self-efficacy pencegahan HIV/AIDS yang tinggi dapat menurunkan perilaku seksual berisiko. Selain itu, remaja yang tidak merasakan depresi akan memiliki self-efficacy pencegahan HIV/AIDS yang tinggi. Lebih lanjut Givaudan, Van de Vijver, Poortinga, Leenen, and Pick (2007) menjelaskan bahwa program untuk meningkatkan pencegahan terhadap infeksi HIV/AIDS pada remaja dapat dilakukan melalui pengembangan self-efficacy. Dengan demikian, manajemen self-efficacy yang tepat dalam pencegahan HIV/AIDS pada remaja dapat mengurangi risiko terjadinya infeksi HIV/AIDS pada remaja tersebut.

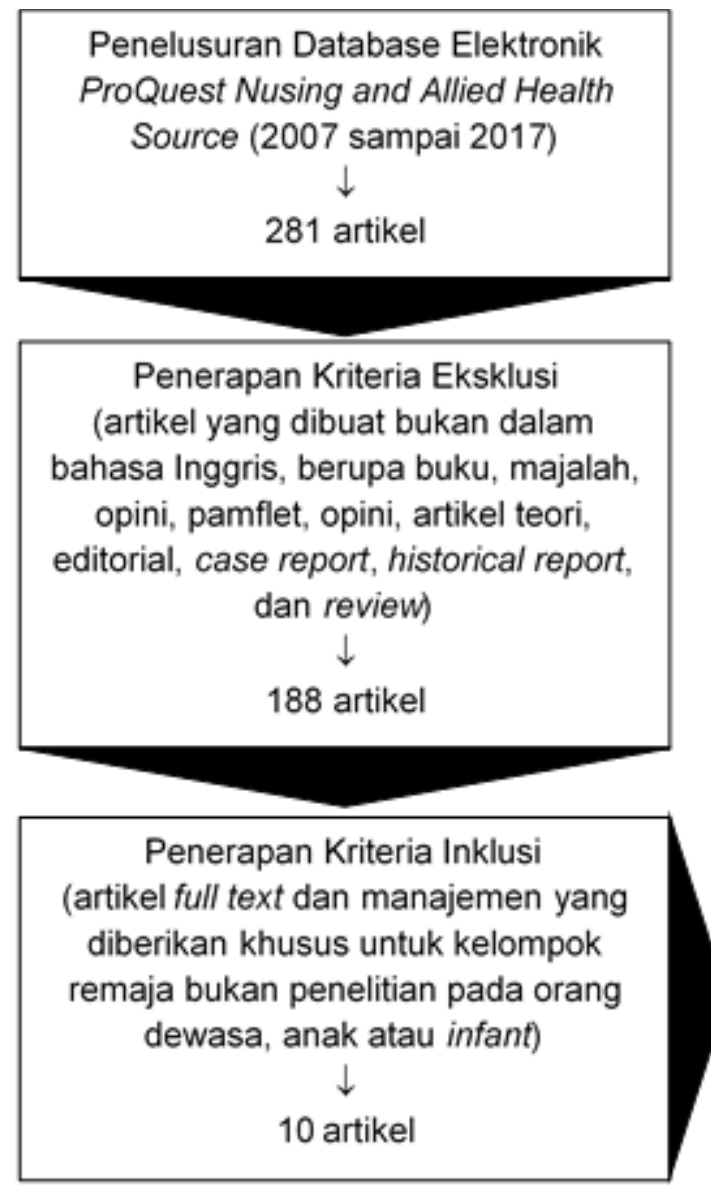

\section{METODE PENELITIAN}

Penelitian ini merupakan sebuah literature review dari beberapa penelitian original dengan metode randomized-controlled trial (RCT). Kajian ini bertujuan untuk mengetahui manajemen pada remaja dalam mengembangkan self-efficacy dalam melakukan pencegahan HIV/AIDS. Pencarian literatur yang dipublikasikan dilakukan secara sistematis untuk mengidentifikasi berbagai penelitian yang melaporkan tentang protokol atau manajemen self-efficacy pencegahan HIV/AIDS pada kelompok remaja. Artikel diperoleh dengan penelusuran dari ProQuest Nusing and Allied Health Source (Januari 2007 sampai Februari 2017), menggunakan kata kunci pencarian "selfefficacy", "HIVIAIDS", "intervention", "program" dan "adolescents".

\section{HASIL}

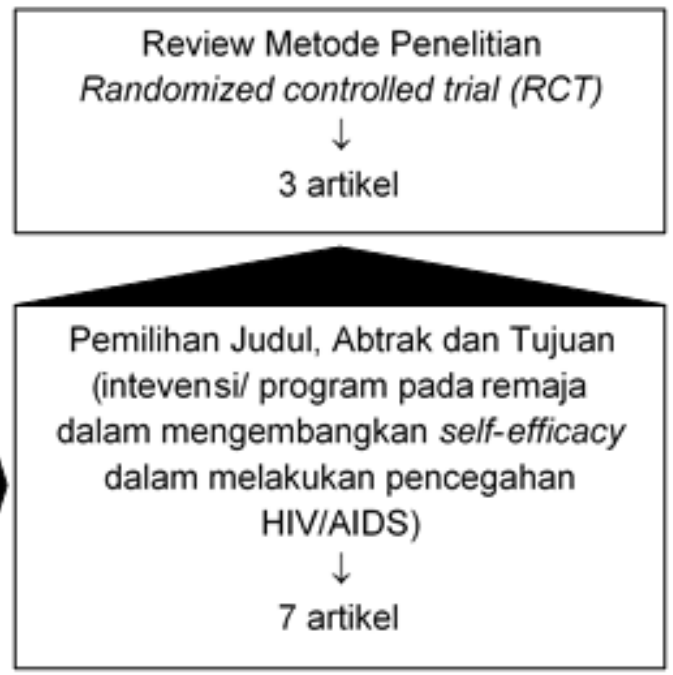


Gambar 1. Diagram alir dari proses penelusuran

Hasil penelusuran artikel melalui penelusuran ProQuest Nusing and Allied Health Source dengan kata kunci yang telah ditentukan sebanyak 281. Sebanyak 188 artikel ditemukan dengan menerapkan kriteria ekslusi dan berkurang lagi menjadi 10 artikel melalui penerapan kriteria inklusi. Sebanyak 7 artikel direduksikan melalui pemilihan judul, abstrak dan tujuan karena tidak memenuhi kriteria yang ditentukan yaitu manajemen atau intevensi yang dilakukan dapat dilakukan oleh remaja dalam mengembangkan self-efficacy pencegahan HIV/AIDS. Setelah skrining lebih lanjut melalui pemilihan metode penelitian yaitu randomized-controlled trial (RCT), terpilih 3 artikel yang dilakukan review. Gambar 1 menunjukkan diagram alir dari proses penelusuran.

Kamo, Carlson, Brennan, and Earls (2008) melakukan penelitian untuk mengembangkan program atau intervensi pencegahan epidemik HIV/AIDS. Penelitian ini merupakan cluster randomized-contrlled trial (RCT) yang bertujuan mengembangkan program Young Citizen, yaitu program promosi kesehatan berfokus kepada remaja untuk meningkatkan self-efficacy melalui pendidikan publik dan komunitas. Penelitian ini dilakukan pada 15 komunitas masyarakat di Distrik Moshi, Kilimanjaro, Tanzania. dimana rata-rata jumlah penduduk yang terlibat sebanyak 2000-4000 orang, yang secara acak dialokasikan menjadi kelompok perlakukan dan kelompok kontrol. Dalam setiap kelompok komunitas, 24 orang remaja berusia 10 - 14 tahun terpilih mengikuti program yang dilaksanakan selama 28 minggu. Penelitian terhadap program yang dilaksanakan ini akan membangun pemahaman dan keyakinan terkait dasar ilmiah dan konteks sosial dari infeksi HIV, tes dan pengobatan di komunitas mereka.

Program Young Citizen (YC) merupakan intervensi tingkat individu dan komunitas. Kurikulum dalam program ini terdiri atas lima modul yaitu: Group Formation, Understanding our Community, Health and our Community, Making Assessments and Taking Action in our Community and InterActing in our Community. Selain itu, intervensi yang diberikan pada program ini yaitu melalui drama mengenai penyakit HIV/AIDS. Program ini berfokus pada perilaku sosial, sikap dan kendali emosional yang berdampak terhadap kesehatan mental individu. Penilaian terhadap keberhasilan program ini dilakukan sebelum dan sesudah perlakukan melalui penilaian tingkat selfefficacy individu dan keluarga. Program tersebut juga diketahui dapat membangun tingkat kepercayaan, ekspresi dan kendali emosional diri. Hasil penelitian menunjukkan bahwa program melalui pendekatan promosi kesehatan yang dilakukan secara sistematik dan kolektif dapat mengembangkan selfefficacy remaja terhadap pencegahan perilaku seksual yang berisiko terhadap HIV/AIDS.

Penelitian yang hampir sama dilakukan DiClemente et al. (2009) terhadap 715 remaja perempuan berusia $15-21$ tahun yang bertujuan untuk mengevaluasi efikasi intervensi dalam menurunkan insiden penyakit menular seksual dan HIV melalui perilaku pencegahan dan mediator psikososial. Penelitian randomized controlled trial ini dilakukan di klinik kesehatan Atlanta, Georgia, Amerika Serikat. Penelitian ini menggunakan pendekatan kualitatif dan tes lapangan. Intervensi dikenal dengan nama HORIZONS yang terdiri dari tiga komponen yaitu (1) sesi pemberian edukasi oleh edukator terlatih mengenai pencegahan penyakit menular seksual dan HIV yang dilakukan selama 4 jam untuk setiap kelompok; (2) menyediakan pelayanan gratis pemeriksaan laboratorium untuk mengetahui kemungkinan infeksi menular seksul bagi pasangan laki-laki dari remaja yang mengikuti penelitian; (3) menghubungi setiap remaja secara singkat 
(15 menit) melalui telepon sebanyak 4 kali untuk melakukan dorongan dalam pencegahan perilaku seksual berisiko. Hasil penelitian menunjukkan bahwa remaja perempuan yang mengikuti program memiliki self-efficacy yang lebih tinggi terhadap pencegahan perilaku berisiko HIV dan penyakit menular seksual lainnya dan kejadian infeksi clamydial lebih sedit terjadi pada kelompok perlakuan dibandingkan kelompok kontrol.

Penelitian Dilorio, McCarty, Resnicow, Lehr, and Denzmore (2007) bertujuan untuk mempengaruhi perilaku remaja laki-laki salah satunya self-efficacy melalui intervensi pencegahan HIV. Penelitian ini menggunakan metode group-randomized trial terhadap kelompok perlakuan dan kelompok kontrol. Intervensi dilakukan selama 12 bulan dengan pengkajian atau follow-up wawancara diberkan pada bulan ke-3, ke-6 dan ke-12. Sejumlah 277 ayah dan anak laki-lakinya diikutsertakan dalam penelitian ini. Intervensi yang dilakukan disebut The REAL Men Program yang merupakan singkatan dari Responsible, Empowered, Aware, Living. Program ini didasarkan pada social cognitive theory yang bertujuan mempengaruhi perilaku seksual dengan pendekatan faktor personal, lingkungan dan sikap. Faktor personal termasuk self-efficacy, hasil akhir yang diharapkan dan tujuan kinerja, sedangkan faktor lingkungan termasuk dorongan dan dukungan diri orang lain.

Program The Real Men, melibatkan ayah sebagai sumber informasi dan komunikasi bagi remaja. Topik yang menjadi fokus pada program ini tentang monitoring orang tua dan hubungan dengan teman sebaya, seksualitas pada masa remaja, serta penyebaran dan pencegahan HIV/AIDS. Program ini dilaksanakan dengan memeperhatikan sikap perilaku dan latihan dalam bersikap melalui role play, diskusi, permainan dan rekaman. Intervensi dilaksanakan selama 2 jam dalam satu minggu. Setiap partisipan diberikan buku petujuk atau manual yang memudahkan pelaksanaan program ini.

Hasil penelitian menunjukkan bahwa prevalensi penundaan hubungan seksual dan penggunaan kondom yang diamati antara remaja laki-laki yang ayahnya berpartisipasi dalam intervensi lebih tinggi. Ayah pada kelompok intervensi melaporkan secara signifikan bahwa intensitas diskusi yang lebih lanjut tentang seksualitas dan keinginan untuk membahas seksualitas lebih besar dari pada ayah pada kelompok kontrol. Hal ini menunjukkan bahwa peran ayah dalam meningkatkan self-efficacy pada remaja dalam pencegahan perilaku berisiko HIV sangat penting. Ayah dapat berfungsi sebagai pendidik penting pada pencegahan HIV dan seksualitas untuk anak-anak mereka.

\section{PEMBAHASAN}

Infeksi HIV/AIDS sangat erat kaitannya dengan perilaku seksual berisiko. Sama seperti Saewyc et al. (2006), yang menemukan bahwa remaja baik laki-laki maupun perempuan memiliki kerentanan untuk terinfeksi HIV karena kecenderungan tinggi untuk terlibat pada perilaku seksual berisiko. Oleh karena itu diperlukan intervensi yang dapat mencegah terjadinya risiko HIV/AIDS ini. Dalam rangka mendorong inisiasi program yang dapat mengurangi perilaku seksual berisiko HIV pada remaja, diperlukan pemahaman multidimensional yang dapat mempengaruhi keinginan dan kinerja suatu perilaku (Jones, Thomas-Purcell, Lewis-Harris, \& Richards, 2016).

Berbagai penelitian telah mengungkapkan bahwa faktor penentu dan konsekuensi dari perilaku seksual pada kalangan remaja sebagian besar terkait dengan self-efficacy, ide-ide normatif, dan keluarga, serta pengaruh teman sebaya. Hasil kajian menemukan bahwa intervensi untuk meningkatkan self-efficacy remaja pada pencegahan perilaku seksual berisiko HIV dapat dilakukan melalui pendekatan berbasis individu, keluarga, masyarakat dan 
media teknologi, seperti yang digambarkan pada Gambar 2.

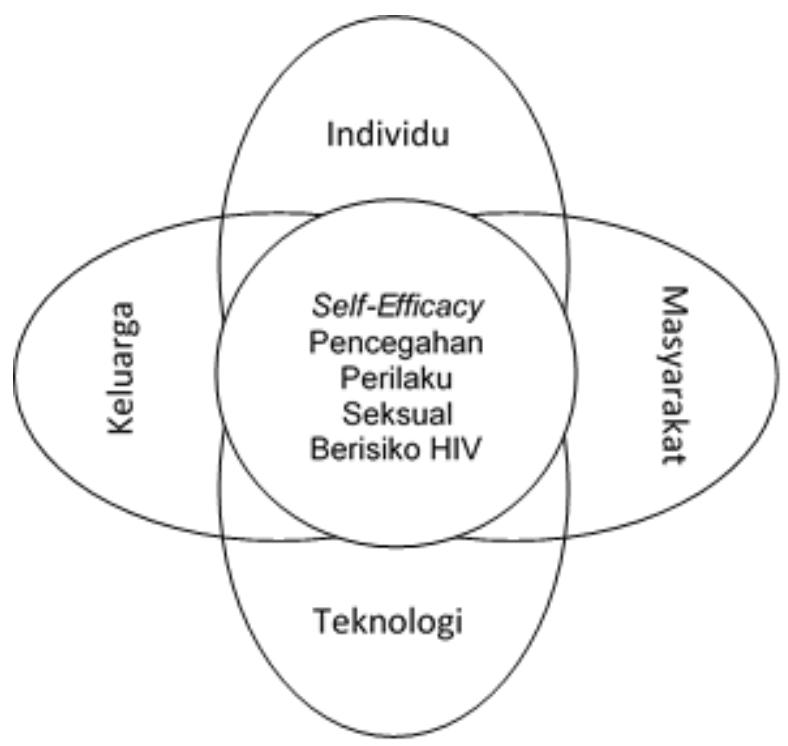

Gambar 2. Pendekatan Intervensi Self-Efficacy Pencegahan Perilaku Seksual Berisiko HIV

Self-efficacy dapat diartikan sebagai persepsi pribadi dari seseorang untuk meyakini kemampuan dirinya dalam melakukan perilaku yang diyakini akan mendapat hasil yang sukses (Luszczynska, Gutiérrez-Doña, \& Schwarzer, 2005). Pencegahan terhadap infeksi HIV/AIDS pada kalangan remaja dapat dilakukan dengan mengembangkan berbagai program atau intervensi melalui penguatan selfefficacy remaja dalam mencegah perilaku seksual berisiko.

Pencegahan perilaku seksual yang berisiko terjadi infeksi HIV/AIDS pada remaja dapat dilakukan melalui program promosi kesehatan. Promosi kesehatan yang dikembangkan berfokus untuk mengembangkan tingkat kepercayaan diri remaja terutama membangun self-efficacy atau keyakinan akan kemampuan diri agar berhasil melakukan tindakan pencegahan perilaku seksual berisiko HIV. Promosi kesehatan juga berkaitan dengan kemampuan komunikasi yang efektif. Sama seperti yang diungkapkan Obregon and Airhihenbuwa (2000) bahwa strategi komunikasi efektif merupakan komponen kritis dalam upaya global pencegahan dan pendidikan HIV/AIDS.
Program promosi kesehatan yang dikembangkan oleh Kamo et al. (2008) menggunakan pendekatan promosi kesehatan dengan tujuan untuk meningkatkan self-efficacy remaja melalui pendidikan kesehatan dalam lingkup perorangan dan komunitas. Program ini berfokus kepada perubahan perilaku sosial, sikap dan kendali emosional. Selain itu, struktur pendidikan yang terdapat pada program ini memungkinkan remaja untuk mendapatkan pengetahuan ilmiah, kemampuan komunikasi dan keterampilan berpikir kritis dalam menghadapi permasalahan HIV/AIDS yang terjadi disekitarnya.

Di samping itu, program yang dikenal dengan nama Young Citizen ini juga berdampak terhadap collective-efficacy pada tingkatan komunitas yang lebih luas. Promosi kesehatan yang lebih luas diberikan kepada masyarakat sekitar baik melalui berbagai cara penyampaian seperti diskusi dan drama memberikan pengaruh terhadap norma sosial dan ekpektasi masyarakat tentang HIV/AIDS (Carlson, Brennan, \& Earls, 2012). Intervensi berbasis drama yang diberikan pada program ini juga secara signifikan dapat meningkatkan keinginan 
untuk melakukan VCT HIV/AIDS pada orang dewasa (Middelkoop, Myer, Smit, Wood, \& Bekker, 2006). Collective-efficacy masyarakat juga membantu memecahkan salah satu permasalahan disekitar orang dengan HIV/AIDS (ODHA) yaitu berkurangnya stigma negatif pada ODHA. Selain itu, program yang melibatkan keikutsertaan masyarakat akan membantu dalam melakukan pengawasan terhadap tindakan atau perilaku seksual berisiko HIV yang mungkin akan dilakukan oleh remaja di lingkungan masyarakat tersebut (Carlson et al., 2012).

Self-efficacy dan kemampuan komunikasi yang baik berhubungan dengan kemungkinan remaja untuk terlibat dalam perilaku seksual berisiko HIV. Hal ini sangat penting karena terkait dengan meningkatnya kebutuhan promosi kesehatan bagi remaja dan memastikan bahwa pengetahuan kesehatan seksual dan reprodiksi serta informasi mengenai penyakit HIV/AIDS, penularan dan pencegahannya harus diterima oleh remaja.

Pendekatan yang hampir sama dilakukan oleh Dilorio et al. (2007) dalam upaya pencegahan perilaku seksual berisiko HIV pada remaja. Penelitian dengan metode randomized-controlled trial ini menggunakan pendekatan melalui pemberian edukasi kesehatan dalam mencegah penyakit menular seksual dan HIV pada kelompok remaja. Namun sedikit berbeda, intervensi yang diberikan kepada remaja ini tidak hanya melibatkan individu remaja sendiri tetapi mengikutsertakan peran ayah sebagai sumber informasi dan komunikasi bagi remaja.

Program yang digagas dengan nama REAL Men atau singkatan dari responsible, empowered, aware, living, merupakan program yang bertujuan untuk meningkatkan self-efficacy remaja untuk menunda keinginan hubungan seksual dini pada remaja dan kemampuan komunikasi mengenai seksualitas antara ayah dan anak. Program ini juga mendorong ayah untuk mampu berkomunikasi terbuka dalam mendikusikan mengenai informasi spesifik HIV/AIDS, penularan dan pencegahannya.
Sebaliknya, remaja juga memiliki kesempatan yang sama untuk berdiskusi dan berbincang dengan ayahnya terkait masalah seksualitas yang dialaminya. Di samping itu, keterlibatan ayah dalam intervensi pencegahan perilaku seksual berisiko HIV pada remaja juga mampu meningkatkan kemampuan self-efficacy remaja dalam upaya pencegahan (Dilorio et al., 2007).

Peran orang tua dalam pencegahan HIV/AIDS sangat penting terutama bagi anaknya yang masih usia remaja. Pada kebanyakan kasus, peran orang tua dalam hal ini sangat kecil. Orang tua kadang kurang peka terhadap informasi kesehatan seksual yang bermanfaat untuk disampaikan kepada anaknya dan bahkan gagal menyampaikan informasi sensitif terkait perilaku seksual dan HIV/AIDS. Orang tua baik ayah bagi aank laki-lakinya ataupun ibu bagi anak perempuannya merupakan sumber informasi pendidikan kesehatan seksual dan reproduksi yang paling efektif dan paling dekat.

Berbeda dengan DiClemente et al. (2009) dimana pendekatan promosi kesehatan untuk meningkatkan self-efficacy pencegahan perilaku seksual berisiko HIV dilakukan dengan menggunakan media teknologi. Peningkatan self-efficacy pada remaja untuk menghindari perilaku seksual berisiko HIV dilakukan dengan beberapa cara, mulai dari pemberian informasi oleh edukator terlatih secara tatap muka sebagai tahap awal. Selanjutnya dilakukan melalui media teknologi komunikasi seperti telepon untuk memberikan dorongan kepada remaja agar selalu berpegang teguh pada keyakinannya untuk tidak melakukan perilaku seksual berisiko yang mengarah kepada infeksi HIV.

Promosi kesehatan untuk mengingatkan remaja mengenai pencegahan perilaku seksual berisiko HIV melalui penggunaan teknologi menjadi salah satu intervensi pencegahan infeksi HIV pada remaja karena sangat sesuai dengan perkembangan teknologi saat ini. Pemberian informasi melalui telepon atau bahkan telepon seluler dengan memanfaatkan fasilitas internet lebih 
mudah dilaksanakan bahkan oleh orang tua atau suatu komunitas tertentu. Intervensi melalui penggunaan teknologi komputer relatif mudah untuk dilakukan secara berkelanjutan oleh siapa pun selama memiliki kemampuan menggunakan teknologi tersebut.

Lightfoot, Comulada, and Stover (2007) mengatakan remaja yang berpartisipasi dalam intervensi berbasis komputer secara signifikan lebih sedikit terlibat dalam aktivitas seksual. Penggunaan teknologi komunikasi dan berbasis komputer dapat membantu remaja mempelajari kemampuan mencegah infeksi HIV dan mengembangkan selfefficacy remaja untuk mengimplementasikan keterampilan ini. Selain itu, bagi remaja teknologi komputer merupakan teknologi yang mudah untuk diakses dan digunakan. Informasi yang diperoleh melalui teknologi komputer pun mudah untuk diperoleh.

\section{KESIMPULAN}

Self-efficacy pencegahan perilaku seksual berisiko HIV pada remaja merupaka kemampuan diri remaja untuk yakin dapat dan berhasil melakukan tindakan pencegahan terhadap berbagai kemungkinan perilaku seksual yang berisiko terjangkitnya infkesi HIV. self-efficacy ini dapat dikembangkan melalui berbagai cara dan program terutama melalui pendidikan kesehatan. Intervensi promosi kesehatan untuk mengembangkan Self-efficacy pencegahan perilaku seksual berisiko HIV ini dapat dilakukan melalui pendekatan secara individu, keluarga, masyarakat dan melalui penggunaan teknologi komputer. Intervensi yang digunakan melalui bebagai ini memberikan kesempatan besar agar remaja mampu memiliki self-efficacy yang tinggi terhadap pencegahan perilaku seksual berisiko HIV sehingga generasi remaja ini akan terbebas dari infeksi HIV/AIDS. Adapun saran untuk penelitian selanjutnya yaitu mengenai mengenai intervensi berbasis teknologi yang lebih luas dan lebih dikenal oleh kalangan remaja untuk mengembangkan efikasi diri dalam pencegahan perilaku berisiko HIV.

\section{DAFTAR PUSTAKA}

Bankole, Akinrinola, Singh, Susheela, Woog, Vanessa, \& Wulf, Deirdre. (2004). Risk and protection: youth and HIV/AIDS in sub-Saharan Africa.

Biglan, Anthony, Brennan, Patricia A., Foster, Sharon L., \& Holder, Harold D. (2004). Helping Adolescents at Risk: Prevention of Multiple Problem Behaviors: Guilford Press.

Blum, Robert W, \& Nelson-Mmari, Kristin. (2004). The health of young people in a global context. Journal of Adolescent Health, 35(5), 402-418.

Carlson, Mary, Brennan, Robert T, \& Earls, Felton. (2012). Enhancing adolescent self-efficacy and collective efficacy through public engagement around HIV/AIDS competence: a multilevel, cluster randomized-controlled trial. Social science \& medicine, 75(6), 10781087.

DiClemente, Ralph J, Wingood, Gina M, Rose, Eve S, Sales, Jessica M, Lang, Delia L, Caliendo, Angela M, . . . Crosby, Richard A. (2009). Efficacy of sexually transmitted disease/human immunodeficiency virus sexual risk-reduction intervention for African American adolescent females seeking sexual health services: A randomized controlled trial. Archives of Pediatrics \& Adolescent Medicine, 163(12), 1112-1121.

Dilorio, Colleen, McCarty, Frances, Resnicow, Ken, Lehr, Sally, \& Denzmore, Pamela. (2007). REAL men: A group-randomized trial of an HIV prevention intervention for adolescent boys. American Journal of Public Health, 97(6), 1084-1089. 
Givaudan, Martha, Van de Vijver, Fons JR, Poortinga, Ype H, Leenen, Iwin, \& Pick, Susan. (2007). Effects of a School-Based Life Skills and HIVPrevention Program for Adolescents in Mexican High Schools1. Journal of Applied Social Psychology, 37(6), 1141-1162.

Gregson, Simon, Nyamukapa, Constance A, Garnett, Geoffrey P, Mason, Peter R, Zhuwau, Tom, Caraël, Michel, . . . Anderson, Roy M. (2002). Sexual mixing patterns and sex-differentials in teenage exposure to HIV infection in rural Zimbabwe. The Lancet, 359(9321), 1896-1903.

Jones, Desiree M. P. H., Thomas-Purcell, Kamilah B. PhD M. P. H. Ches, Lewis-Harris, Jacquelyn PhD, \& Richards, Christine M. P. H. PhD. (2016). Correlation between selfefficacy in sexual negotiation and engagement in risky sexual behaviors: Pilot study of adolescents attending a secondary school in Grenada, West Indies. International Public Health Journal, 8(3), 397-405.

Kamo, Norifumi B. A., Carlson, Mary PhD M. P. A., Brennan, Robert T. EdD, \& Earls, Felton M. D. (2008). Young Citizens as Health Agents: Use of Drama in Promoting Community Efficacy for HIV/AIDS. American Journal of Public Health, 98(2), 201204.

Komisi Penanggulangan AIDS Nasional. (2015). Laporan Kegiatan KPAN 2014. Komisi Penanggulangan AIDS Nasional (KPAN).

Lee, Yi-Hui, Salman, Ali, \& Fitzpatrick, Joyce J. (2009). HIV/AIDS preventive selfefficacy, depressive symptoms, and risky sexual behavior in adolescents: A cross-sectional questionnaire survey. International journal of nursing studies, 46(5), 653-660.

Lightfoot, Marguerita, Comulada, W. Scott, \& Stover, Gabriel. (2007). Computerized HIV Preventive Intervention for Adolescents: Indications of Efficacy. American Journal of Public Health, 97(6), 10271030.

Lindberg, Laura Duberstein, Boggess, Scott, \& Williams, Sean. (2000). Multiple Threats: The Co-Occurrence of Teen Health Risk Behaviors.

Luszczynska, Aleksandra, Gutiérrez-Doña, Benicio, \& Schwarzer, Ralf. (2005). General self-efficacy in various domains of human functioning: Evidence from five countries. International Journal of Psychology, 40(2), 80-89.

Middelkoop, Keren, Myer, Landon, Smit, Joalida, Wood, Robin, \& Bekker, Linda-Gail. (2006). Design and evaluation of a drama-based intervention to promote voluntary counseling and HIV testing in a South African community. Sexually transmitted diseases, 33(8), 524-526.

Obregon, Rafael, \& Airhihenbuwa, Collins $\mathrm{O}$. (2000). A critical assessment of theories/models used in health communication for HIV/AIDS. Journal of health communication, 5(sup1), 515.

Saewyc, Elizabeth, Skay, Carol, Richens, Kimberly, Reis, Elizabeth, Poon, Colleen, \& Murphy, Aileen. (2006). Sexual orientation, sexual abuse, and HIV-risk behaviors among adolescents in the Pacific Northwest. American journal of public health, 96(6), 1104-1110.

UNAIDS. (2014). Global report: UNAIDS report on the global AIDS epidemic 
2013. Joint United Nations Programme on HIV/AIDS Geneva.

UNAIDS. (2016). Global AIDS Update 2016.

The Joint United Nations Programme on HIV/AIDS, Geneva.
UNICEF. (2002). Young people and HIV/AIDS: Opportunity in crisis: United Nations Children's Fund, Joint United Nations Programme on HIV/AIDS and World Health Organization. 